\title{
Selection of inocula conditioning methodologies for the anaerobic digestion of food waste
}

\author{
Selección de metodologías de acondicionamiento de inóculos para la digestión anaerobia de \\ residuos de alimentos
}

\author{
Brayan Alexis Parra-Orobio (i) ${ }^{1 *}$, Melkin Nieto-Mendoza (1) ', Diego Rivera-Henao (1) ', Pablo Cesar Manyoma-Velásquez \\ (1) ${ }^{2}$, Patricia Torres-Lozada \\ ${ }^{1}$ Grupo de Investigación Estudio y Control de la Contaminación Ambiental - ECCA, Facultad de Ingeniería, Universidad del Valle. Calle 13 \\ \# 100-00. C.P. 25360. Cali, Colombia. \\ ${ }^{2}$ Grupo de Investigación Logística y producción - LOGYPRO, Facultad de Ingeniería, Universidad del Valle. Calle 13 \# 100-00. C. P. 25360. \\ Cali, Colombia.
}

\section{CITE THIS ARTICLE AS:}

B. A. Parra, M. Nieto, D. Rivera, P. C. Manyoma, and P. T. Lozada, “Selection of inocula conditioning methodologies for the anaerobic digestion of food waste", Revista Facultad de Ingeniería Universidad de Antioquia, no. 92, pp. 9-18, Jul-Sep 2019. [Online]. Available: https://www . doi.org/10.17533/ udea.redin. 20190510

\section{ARTICLE INFO:}

Received: November 14, 2018

Accepted: April 22, 2019

Available online: May 08, 2019

\section{KEYWORDS:}

Biogas, methane, multicriteria analysis, solid waste, technological surveillance

Biogás, metano, análisis multicriterio, residuos sólidos, vigilancia tecnológica
ABSTRACT: Food waste (FW) has a high potential for use in biological processes such as anaerobic digestion (AD), especially due to its high content of biodegradable organic matter. To inoculate the reactors, sludge is usually used. The sludge should ideally have good sedimentation and specific methanogenic activity (SMA), which is typical for granular sludge. However, in a Latin American context, the most available and accessible sludges are flocculants with low sedimentation and SMA. Applying technological surveillance between 1975 and 2017, using multicriteria analysis techniques such as analytical hierarchy process (AHP), and consulting with international and national experts, we observed that there were few studies, compared to published studies on the substrates that focused on improving inoculum quality through conditioning to improve its characteristics and maximize methane production. The inoculum-conditioning methodologies identified were grouped into five categories, being the main strategy the addition of nutrients followed by anaerobic digestion with an easily degradable substrate. However, extension of technological surveillance is recommended by incorporating the results published from significant events in the field of anaerobic digestion, such as the Latin American Workshop and Symposium on Anaerobic Digestion and the World Congress on Anaerobic Digestion.

RESUMEN: Los residuos de alimentos (RA) presentan un alto potencial de aprovechamiento mediante procesos biológicos como la digestión anaerobia (DA), especialmente por su alto contenido de materia orgánica biodegradable. Para inocular los reactores, en general se emplean lodos que deben presentar buena sedimentabilidad y actividad metanogénica específica (AME), típico en lodos granulares. Sin embargo, los de mayor disponibilidad y accesibilidad en el contexto latinoamericano, son lodos floculentos de baja sedimentabilidad y AME. Aplicando vigilancia tecnológica desde 1975 hasta 2017, se evidenció escasa literatura enfocada a mejorar la calidad del inóculo mediante acondicionamientos para mejorar sus características y maximizar la producción de metano, en comparación con los estudios publicados sobre el sustrato. Se identificaron diferentes metodologías de acondicionamiento de inóculos, las cuales se agruparon en cinco categorías y mediante la aplicación de técnicas de análisis multicriterio como el proceso de análisis jerárquico (AHP) y con consulta a expertos internacionales y nacionales. Se identificaron las técnicas más utilizadas, siendo las principales, la adición de nutrientes seguida por la digestión anaerobia con un sustrato de fácil degradación. Sin embargo, se recomienda complementar la vigilancia tecnológica, incorporando los resultados publicados en eventos de gran importancia en el campo de la DA como el Seminario-Taller latinoamericano y el Congreso Mundial de Digestión Anaerobia.

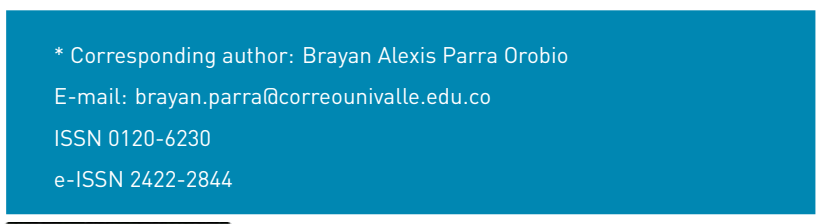

1. Introduction

In the start-up and stabilization of anaerobic digesters to treat food waste (FW), long periods of time are required 
due to limitations in hydrolysis [1] associated with the high content of lignocellulosic material. In many cases, these times increase because the inoculum used is not adapted to the residues or operating conditions [2].

Different strategies have been implemented to increase the production of biogas and optimize the anaerobic digestion (AD) of the FW, one is to improve the biochemical conditions of the different populations of microorganisms that develop during the process, one of the strategies being conditioning of the inoculum. Therefore, the origin and characteristics of the inoculum are of great importance since they determine the initial activity of the process and its performance [3]. It is also known that in the start-up and stabilization of anaerobic digesters for FW treatment, long periods of time are required and in many cases, these increase because the inoculum used is not adapted to the residues and/or operating conditions [2].

The literature does not show standardized methodologies for the conditioning of inocula, so this is a field that presents great possibilities for exploration [4]. Some authors report that predigesting the inoculum for seven days presents good performance for methane production [5]. Some studies report that the biodegradation potential of an inoculum improves after a period of pre-exposure to the substrate, since the hydrolytic enzymes that are involved in the initiation of the anaerobic digestion process need to be induced; this pre-exposure can condition the starting time in the reactors [6].

For the selection of strategies to improve the inoculum, techniques such as multi-criteria analysis (MCA) can be used, based on the idea that the complexity inherent in a decision-making problem with multiple criteria can be solved by prioritizing the problems posed [7]. There is a need to find a vector in this procedure that permits weighing the chosen criteria and allows easy integration (complementarity).

These techniques have been applied, especially in fields such as economics and industrial engineering, and have also been used in the analysis of environmental problems such as management of natural resources, evaluation of environmental pollution and locating facilities for landfills [8-10]. According to a review regarding the management of waste, the AHP/ANP lanalytical hierarchy process/analytic network process) is the most commonly used method to represent different situations [11].

This document presents the application of both technological surveillance tools and AHP analysis to determine the best inoculum conditioning methodology that contributes to the optimization of methane production through the anaerobic digestion of food wastes.

\section{Materials and methods}

To achieve the proposed objective, two central activities were developed: technological surveillance and application of the analytical hierarchy process (AHP), which are detailed below:

\subsection{Technological surveillance}

This allowed identification of the most commonly used methodologies for the conditioning of inocula according to the scientific literature. For this purpose, national and international scientific articles were consulted, in which methodologies were used for the preparation of inocula for AD-FW or similar biowastes. The observation window was between 1975 and 2017. This process was carried out using the technology surveillance software RefViz ${ }^{\circledR}$ $[12,13]$. The search equations are presented in Table 1 and entered into the Scopus database, which is one of the most extensive databases of the technical-scientific literature [14].

The results of the search equations were filtered and grouped into large thematic groups (galaxies) using RefViz ${ }^{\circledR}$. These studies were reviewed in detail, analyzing aspects such as experimental conditions, scale of the study, type of substrate and inoculum, results obtained with each methodology and the feasibility of application in terms of technical complexity, time and costs. Finally, the identified methodologies were grouped according to their similarities.

\subsection{Selection of inoculum conditioning methodologies}

For the selection of the conditioning methodologies that were evaluated, a multicriteria analysis was performed using the AHP method [15]. For the application of the method, three steps were proposed [16]:

\section{Structuring the decision problem in a hierarchical} model

This step involves the decomposition of the decision problem into elements, according to their common characteristics and the formation of a three-level hierarchical model, which is constituted in its first level by the objective of the research, in the second by the established criteria and finally by the alternatives identified or proposed. At the top of the hierarchy is the macro objective of the decision, which is to select the best alternative [16]. For this study, the objective was the selection of the best inocula conditioning methodology from all of those identified in the technological surveillance. 
Table 1 Keywords and equations used in technological surveillance

\begin{tabular}{ll}
\hline Research Equations & \\
\hline Inoculum for Anaerobic Digestion AND Pretreatment & Methane production AND inoculum \\
\hline Inoculum AND Anaerobic Digestion & Methane production AND Pretreatment \\
\hline Pretreatment AND Anaerobic Digestion & Pretreatment AND seed AND Anaerobic Digestion \\
\hline Pretreatment AND inoculum AND Anaerobic Digestion & Improvement AND seed AND Anaerobic Digestion \\
\hline Improvement AND Inoculum AND Anaerobic Digestion & Substrate AND Pretreatment \\
\hline Anaerobic Digestion AND Waste Food & Substrate AND Anaerobic Digestion \\
\hline
\end{tabular}

The second level of the hierarchy contains the attributes or criteria that contribute to the quality of the decision; these are relevant aspects that significantly affect the objective $[17,18]$. These attributes or criteria are established based on recommendations from authors who have worked with $A D$ and on some common characteristics that share the identified conditioning methodologies. The criteria are basically technical and/or economic factors that make one of the identified methodologies more or less attractive at the time of its selection. At the last level of hierarchy, there are decision alternatives or selection options [17]. These alternatives are the conditioning of the inocula identified and each alternative can be composed of several conditioning methodologies that show some similarity.

\section{Peer-to-peer comparisons of the criteria and alternatives}

In this step, the elements of a particular level are compared with respect to a specific element at the next higher level and the judgments of a decision maker on the comparative attractiveness of the elements are captured using the traditional rating scale of the AHP, which consists of a numerical scale of $1,3,5,7$ and 9 . Scale 1 means that the elements contribute equally to the goal. Scale 3 indicates a moderate ranking and that importance and judgment favor one element slightly over the other. Scale 5 indicates a strong ranking where one of the elements is strongly favored with respect to the other. Scale 7 indicates that it is very strong, meaning that one of the elements strongly dominates. Finally, scale 9 represents extreme importance, showing that one of the elements is of the highest order of importance [16]. Thus, all the criteria are compared between peers regarding their relevance to the objective and the alternatives are compared with respect to their relevance to each criterion.

For the present study, the selection of the best conditioning methodologies was made based on the qualifications of national and international experts in $A D$ of biodegradable organic waste, all of whom have vast experience in this field and/or have published in national and international journals; these experts were asked to evaluate, according to their experience, comparisons of both alternatives and criteria.

\section{Hierarchy of the alternatives}

The AHP method compares $n$ elements $E_{1} \ldots E_{n}$, denoting the relative or local weights (priority or importance) of $E_{i}$ with respect to $E_{j}$ for the reason $R_{i j}$. These comparisons are located in a square judgment matrix of order $n$ that is governed by three rules: $R_{i j}>0, R_{i j}=1 / R_{j i}$, for $i$ different from $j$ and $R_{i i}=1$ for all $i$. Such a matrix is a reciprocal matrix (see Figure 2). In this way, the necessary matrices are generated that perform the paired comparisons of the different levels of the defined hierarchical model [18].

The comparison matrix must be consistent, i.e., $E_{i j}=$ $E_{i k} * E_{k j}$, for all the components of the matrix. However, as the matrix is based on human judgments and these are not always consistent, there may be inconsistencies introduced due to the nature of the scale used. This inconsistency is estimated through a measure called the consistency coefficient (- CC) and for human criteria a $\mathrm{CC}$ value less than 0.1 is considered acceptable. If $\mathrm{CC}$ is greater than 0.1 , then judgments must be obtained once more from the decision maker $[8,16]$.

From the qualifications of each of the experts, the local weights of each criterion and of each alternative were calculated, and later the final weights of the alternatives (e.g., the conditioning methodologies). The local weights of the elements were calculated using the concepts of own vector and characteristic value of matrix theory [18].

The normalized eigenvector corresponding to the main eigenvalue of the judgment matrix provides the weights of the corresponding elements. Thus, the element with the greatest local weight is the most important element among all elements in the matrix $[16,17]$. Once the local weights of the criteria matrix and alternative matrices have been obtained, these are added to obtain the final weights of the decision alternatives. In this way, the final weight of alternative $A_{i}$ is calculated using the following hierarchical aggregation rule (Equation 1) [16]. 
Final weight $A_{i}=\sum j\left[\left(\right.\right.$ Weight $A_{i}$ with respect Cj Criteria) Importance of Cj Criterion $\left.)\right]$.

Based on the hierarchy of the final weights, the alternative with the highest final weight is the one best satisfying the objective.

\subsection{Sensitivity analysis}

Sensitivity analysis consists of verifying the stability of the ordering of the alternatives by arbitrarily modifying the relative weighting of the evaluation criteria by a certain amount. This is achieved by varying the weighting of each criterion in a range of $25,33.3,50$ and $100 \%$ while simultaneously observing the behavior of the order of the alternatives. In this case, modifications were made 15 times to the power of the criteria [8].

\section{Analysis and discussion}

\subsection{Technological surveillance}

From the surveillance performed using the different search equations, we found a large number of scientific articles associated with the keywords used, as shown in Table 2.

Table 2 Number of articles found by search equation in the Scopus database

\begin{tabular}{cc}
\hline Search Equations & Articles \\
\hline $\begin{array}{c}\text { Inoculum for } \\
\text { Anaerobic Digestion } \\
\text { AND Pretreatment }\end{array}$ & 82 \\
\hline Inoculum AND Anaerobic Digestion & 0 \\
\hline Pretreatment AND Anaerobic Digestion & 1,609 \\
\hline $\begin{array}{c}\text { Pretreatment AND inoculum } \\
\text { AND Anaerobic Digestion }\end{array}$ & 80 \\
\hline $\begin{array}{c}\text { Improvement AND Inoculum } \\
\text { AND Anaerobic } \\
\text { Digestion }\end{array}$ & 47 \\
\hline Anaerobic Digestion AND Waste Food & 0 \\
\hline Methane production AND inoculum & 695 \\
\hline Methane production AND Pretreatment & 1,106 \\
\hline $\begin{array}{c}\text { Pretreatment AND } \\
\text { seed AND Anaerobic } \\
\text { Digestion }\end{array}$ & 20 \\
\hline Improvement AND seed \\
AND Anaerobic Digestion \\
\hline Substrate AND Pretreatment \\
\hline Substrate AND Anaerobic Digestion \\
\hline Total \\
\hline
\end{tabular}

During the processing of the research found using the $\mathrm{RefViz}^{\circledR}$ software, it was possible to obtain a grouping of 8 galaxies, for a total of 667 articles. Figure 1 shows the distribution of the different galaxies classified by the common theme of the articles that compose them, as well as the number of items on each galaxy.

Figure 1 shows that galaxy G7 is associated with pretreatments of the inoculum; the rest are associated more strongly with pretreatments of the substrate. Among the works associated with the inoculum, highlight as a complex and crucial factor for AD, since this process is based on the metabolic characteristics of microorganisms and is much more efficient when there is an inoculum with good sedimentation and intense microbiological activity $[3,4,19,20]$.

From a second detailed review of the different scientific articles, studies were identified in which some type of method of conditioning or modification of the original conditions of different inocula used in the $A D$ of biodegradable organic waste had been applied. The conditioning methodologies presented in Table 3 share certain characteristics in common, which allows framing them in groups according to the type of conditioning performed, as well as the general objective to be achieved with each conditioning type.

According to the previous table, the predominant conditioning methodology in the studies is physical in nature, using exposure of the inoculum to a certain temperature for a period of time (incubation). In general, this temperature is the same at which the AD of the substrate develops. This conditioning seeks to generate an inoculum that is adapted to the thermal conditions for which the digestion will take place. Incubation of the inoculum is widely recommended in the literature, since it stands out as an important variable that can affect the methane production results $[5,25,49,50]$.

Chemical and biological conditioning are applied to a lesser extent than the aforementioned, with these conditions it is sought to improve some characteristics of the inoculum, such as sedimentation by the addition of coagulants (such as $\mathrm{FeCl}_{3}$ ). This characteristic allows measurement of the capacity and efficiency in sludge retention, which makes it an important variable for evaluating the improvement of sludge quality used as an inoculum in AD [51]. Although the addition of a coagulant can help improve the sedimentation of the inoculum, it can 


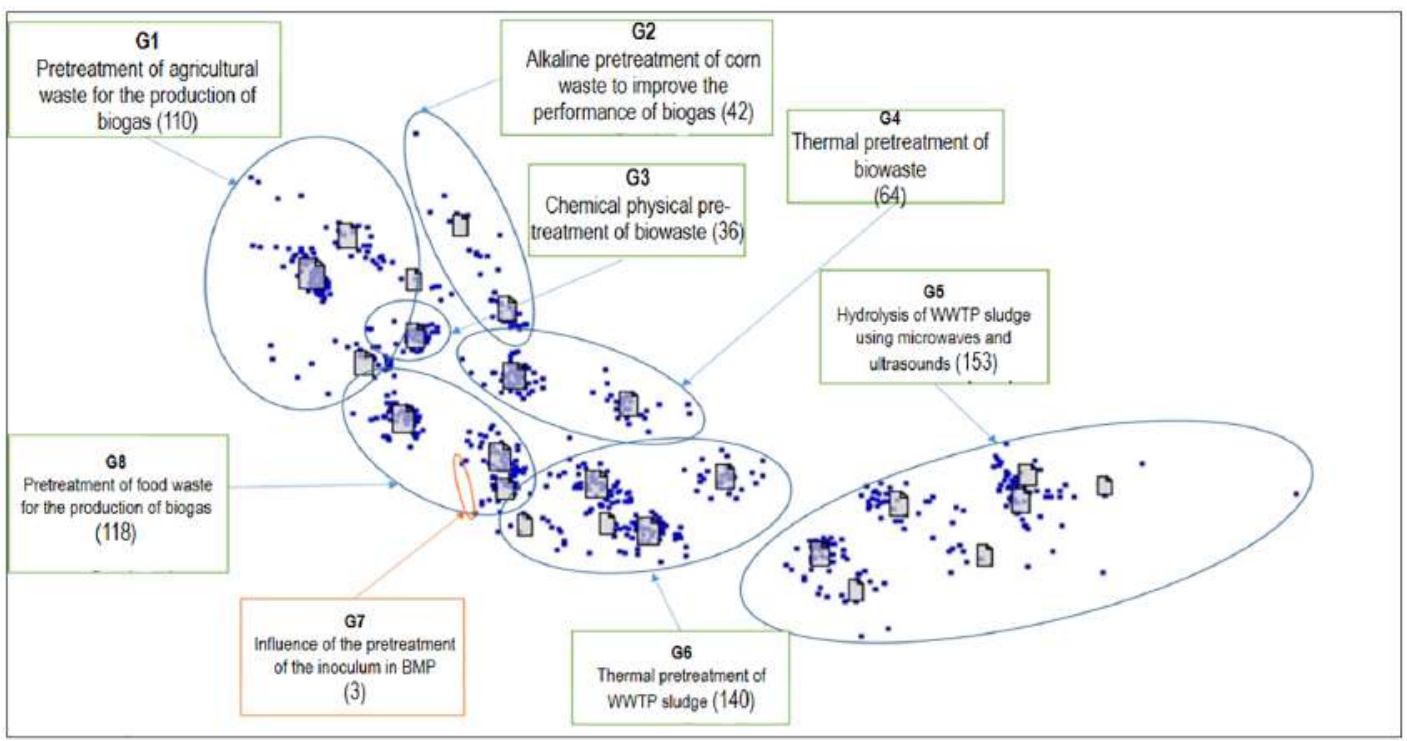

Figure 1 Consolidation of galaxies

Table 3 Groupings of inocula conditioning methodologies

\begin{tabular}{lclll}
\hline Type & Number Studies & Source & Objective & Classification \\
\hline Incubation & 19 & {$[3,5,20-36]$} & $\begin{array}{l}\text { Adapt the inoculum } \\
\text { to a certain } \\
\text { temperature }\end{array}$ & Physical \\
\hline Addition of coagulant & 2 & {$[37,38]$} & $\begin{array}{l}\text { Improve } \\
\text { sludge } \\
\text { sedimentability }\end{array}$ & Chemical \\
\hline $\begin{array}{l}\text { Incubation with } \\
\text { easy degradation } \\
\text { substrate }\end{array}$ & 5 & {$[39-44]$} & $\begin{array}{l}\text { Improve the } \\
\text { capacity of } \\
\text { microorganisms to } \\
\text { assimilate a } \\
\text { substrate }\end{array}$ & Biological \\
\hline $\begin{array}{l}\text { Addition of nutrients } \\
\text { Thickening of the inoculum }\end{array}$ & 2 & {$[45,46]$} & $\begin{array}{l}\text { Facilitate enzymatic } \\
\text { reactions }\end{array}$ & Chemical \\
\hline & 5 & {$[5,20,28,47,48]$} & $\begin{array}{l}\text { Increase the } \\
\text { concentration of the } \\
\text { biomass in the sludge }\end{array}$ & Physical \\
\hline
\end{tabular}

also generate inhibition of methanogenic microorganisms, which would be detrimental to the AD process [37, 52].

The addition of nutrients has also been used for conditioning prior to $A D$ to improve the quality of the inoculum. It has been identified that a lack of some nutrients is the main reason behind the poor performance of AD processes. Several studies have concluded that the dosage of nutrients (macro and micro) as a complement, can stimulate the production of methane, as well as improve the stability of the process; for example, conserving the buffer capacity to avoid the accumulation of VFAs and/or providing a minimum level of alkalinity and facilitating enzymatic reactions [53]. However, in the few studies seen in the literature regarding this type of conditioning, their effect is not directly evaluated, nor do they appear as a crucial factor for $A D[45,46,54]$.

Regarding biological conditioning, there is very little literature. Authors report that preincubating the inoculum before the $A D$ process to enrich the microorganisms degrading a substrate of interest by adding small amounts of said substrate or a similar but more easily degradable substrate should improve the performance of the $A D$ when a high load of the substrate of interest is applied [40]. Some studies report the addition of specific enzymes such as peptidase, carbohydrolase and lipase as biological conditioning to the AD system [55]. These enzymes could 
act as an adjunct in the activity of the inocula allowing easier degradation of substrates such as FW.

The lack of a standardized methodology for conditioning of the inoculum is seen with factors such as temperature, since many authors work with different values, ranging from 35 to $55^{\circ} \mathrm{C}$. Similarly, the time for which the inoculum is subjected to these temperatures varies from 3 days to 30 days. Research report that the optimal time interval for which the inoculum should be incubated is between 2 to 7 days [50]. Authors used a minimum time of 21 days for adequate incubation of the inoculum [21]. In some cases, when the inoculum is taken from a reactor which has been fed with a high content of fats or oils, the incubation periods can be longer, to eliminate all of the residual substrate [49]. In addition, it is important to note that subjecting the inoculum to high temperatures $\left(55^{\circ} \mathrm{C}\right)$ increases the degradation of organic matter and the production of biomass [21].

The lack of standardized studies and methodologies to improve inoculum quality can be a limiting factor that has prevented the optimization of $A D$, which justifies the relevance of this study. However, it is important to highlight the importance of continued research of this issue and further searches for other valuable sources of information such as the memoirs of events of great importance in the field of anaerobic digestion such as the Latin American and World Symposium of Anaerobic Digestion that have been taking place in different Latin American countries and the world for some decades.

\subsection{Selection of inocula conditioning methodologies}

For the present study, four criteria were established. The three main factors that must be taken into account in the evaluation of the conditioning methodologies for the $A D$ are: (1) the improvement in the production of biogas, (2) the cost of chemical products used and (3) the required temperature; therefore, an optimal conditioning methodology should require limited capital in terms of operating and maintenance costs, as well as being fast enough in a manner that reduces the times and volumes of the conditioning units [56]. Based on the above, the established criteria are:

Time required for application of the method (C1): This criterion refers to the time required to perform the conditioning of the inoculum properly. Different conditioning methodologies may require different times and those using less time for their application may be more advantageous in terms of: less equipment occupation time, consumption of inputs, energy and/or economic resources and demand of man-hours. For example, for preincubation of inocula, an optimal time of 2 to 7 days has been established [50]. However, have reported longer times for proper preincubation [25].

Use of specialized equipment (C2): This criterion relates to the equipment used to develop inoculation conditioning methodologies. These equipment types may have varying degrees of specialization in terms of their operation and acquisition, and their cost or availability in the country may make them difficult to utilize.

Requirements of chemical or biological inputs (C3): This criterion relates the importance of the use of chemical or biological inputs, with the goal of enriching and improving the inoculum in order to optimize the $A D$ process and to increase the production of methane. In comparison with physical and biological methods, chemical conditioning methods are mainly used, because they are simple and fast [57]. On the other hand, the use of additives can increase the rate of production or increase the speed of start-up of a reactor, but the additional costs must always be balanced with the resulting improvements in the efficiency of the AD process [58].

Improvement of inoculum quality (C4): The objective of conditioning the inoculum is to improve its performance of the $A D$ process to optimize the production of biogas; thus, after conditioning an inoculum with quality deficiencies, an improvement in its physical and microbiological characteristics is expected is to be observed. One of the most important characteristics that allows evaluation of the inoculum quality is the specific methanogenic activity(-SMA); granular inocula are generally more stable and have better SMA and methane production compared to flocculant inocula [59]. Therefore, good conditioning in terms of results would lead to improvement in these characteristics.

Figure 2 shows the hierarchical levels that were used for the application of MCA, where the alternatives are the product of the previously developed technological surveillance.

\section{Hierarchy of the conditioning alternatives}

Based on the qualifications of the experts and compiled by means of a digital questionnaire for the evaluation of criteria and alternatives provided, the final weights of each of the alternatives presented in Table 4 were calculated. In total, 50 experts were consulted, 20 responded to the consultation (12 international and 8 national); for each expert a hierarchy of alternatives was obtained and a resultant geometric mean based on information from all experts was applied to obtain the final hierarchy of alternatives. 


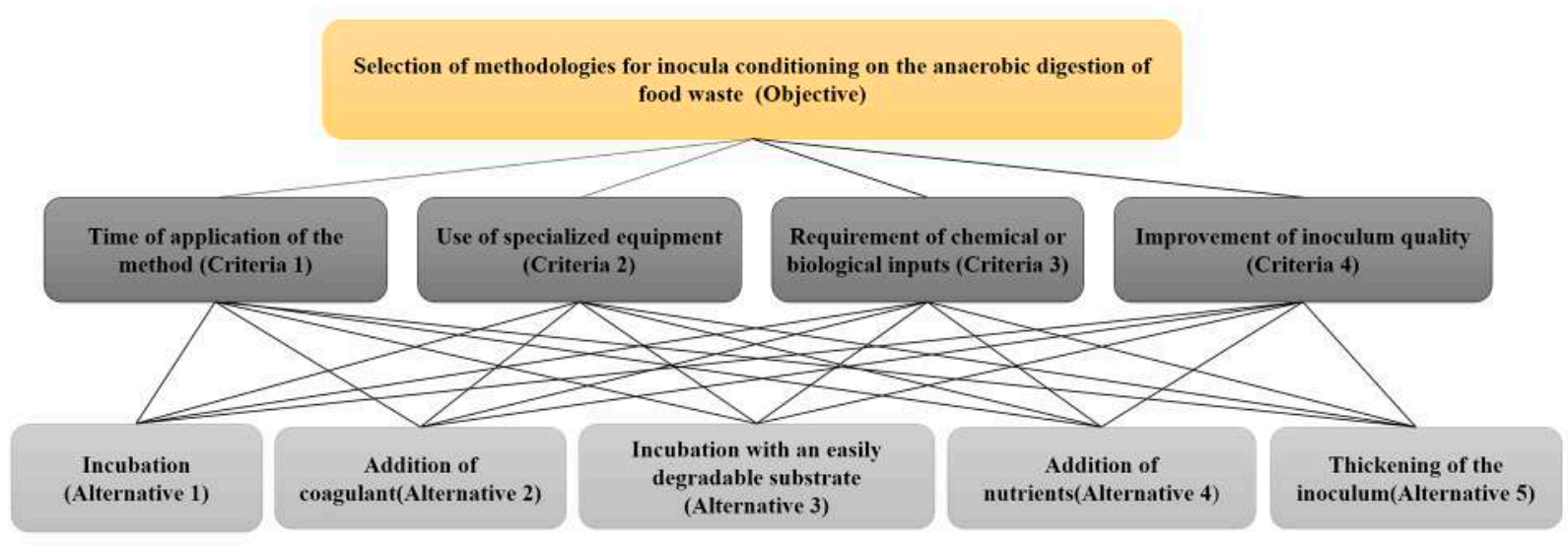

Figure 2 AHP model proposed for the selection of inocula conditioning methodologies

Table 4 Final hierarchy of alternatives for the inocula conditioning methodologies

\begin{tabular}{ccc}
\hline Scale & Alternative & Final weight [\%] \\
\hline 1 & Addition of nutrients & 26.1 \\
\hline 2 & $\begin{array}{c}\text { Incubation with } \\
\text { an easily } \\
\text { degradable substrate }\end{array}$ & 23.3 \\
\hline 3 & Incubation & 22.5 \\
\hline 4 & Thickening of the inoculum & 16.7 \\
\hline 5 & Addition of coagulant & 11.3 \\
\hline
\end{tabular}

Table 4 shows the final ranking of the inoculation conditioning alternatives evaluated using the AHP method.

According to these results, inoculation conditioning methodologies having greater application by the experts correspond to the addition of nutrients and incubation with the addition of an easily degradable substrate (consistency coefficient <0.1: 0.008 ), indicating that the expert panel was consistent in the decision making of the best inoculum conditioning methodology. However, this contrasts with what is identified using technological surveillance, highlighting the need for $A D$ research of waste if the inoculum was previously submitted to a conditioning process.

Through the tools used, the experts also stated some considerations that should be taken into account when selecting a conditioning methodology, among them the most common was the origin and characteristics of the inoculum as this determines its quality and efficiency in the $A D$, and therefore, whether or not there is a need to improve it through conditioning. This is very consistent with what is found in the literature since, in general, the best performing inoculants in $A D$ are granular inocula, which come from highly stable operational anaerobic reactors and are fed with substrates with high concentrations of organic matter. These granular inocula are unlike the flocculant inocula, that are associated with low concentrations of substrates, such as municipal wastewater $[4,51,59,60]$.

Another aspect highlighted was the type of substrate to be treated since, depending on this, the conditioning could be oriented in a different way; operating conditions such as frequency and amount of chemical and biological inputs, as well as monitoring of factors that allow the evolution of the inoculum to be evaluated. All of these are aspects that must be taken into account and controlled in the AD process, since they could determine the success of an inoculation conditioning methodology.

\subsection{Sensitivity analysis}

The most important alternatives according to selection by the panel of experts, were the addition of nutrients and anaerobic digestion with an easily degradable substrate, and showed no variation in the sensitivity analysis. In other words, when the score of each of these criteria was decreased and increased, the order of the 9 alternatives remained constant $(60 \%$ of the iterations), as seen in Table 5. This result shows that the AHP tool is robust and that the selection of alternatives is objective. On the other hand, the sensitivity analysis shows that, when the importance of criteria C2 and C3 increased, the order of the alternatives changed: the alternative incubation increased two positions, being placed as the first preference 6 times; consequently it could also be an alternative to evaluate, considering the purpose and context of the research. On the other hand, it is emphasized that the alternative of adding coagulant is always in the last position, regardless of the increase or decrease of the scores presenting the criteria. 
Table 5 Sensitivity analysis of the conditioning methodologies

\begin{tabular}{|c|c|c|c|c|c|c|c|c|c|}
\hline \multirow[b]{2}{*}{ Number } & \multicolumn{4}{|c|}{ Criteria Weighting (\%) } & \multicolumn{5}{|c|}{ Position of Alternatives } \\
\hline & C1 & $\mathrm{C} 2$ & C3 & C4 & Incubation & $\begin{array}{c}\text { Addition of } \\
\text { coagulant }\end{array}$ & $\begin{array}{c}\text { Incubation } \\
\text { with addition } \\
\text { of sustrate for } \\
\text { easy degradation }\end{array}$ & $\begin{array}{l}\text { Addition } \\
\text { of } \\
\text { nutrients }\end{array}$ & $\begin{array}{c}\text { Thickening } \\
\text { of the } \\
\text { inoculum }\end{array}$ \\
\hline 1 & 100 & 0 & 0 & 0 & 4 & 5 & 2 & 1 & 3 \\
\hline 2 & 0 & 100 & 0 & 0 & 3 & 5 & 2 & 1 & 4 \\
\hline 4 & 0 & 0 & 100 & 0 & 1 & 5 & 3 & 4 & 2 \\
\hline 5 & 0 & 0 & 0 & 100 & 3 & 5 & 2 & 1 & 4 \\
\hline 6 & 50 & 50 & 0 & 0 & 4 & 5 & 2 & 1 & 3 \\
\hline 7 & 0 & 50 & 50 & 0 & 1 & 5 & 2 & 3 & 4 \\
\hline 8 & 0 & 0 & 50 & 50 & 1 & 5 & 3 & 2 & 4 \\
\hline 9 & 50 & 0 & 0 & 50 & 3 & 5 & 2 & 1 & 4 \\
\hline 10 & 0 & 50 & 0 & 50 & 1 & 5 & 2 & 3 & 4 \\
\hline 11 & 50 & 0 & 50 & 0 & 3 & 5 & 2 & 1 & 4 \\
\hline 12 & 33.3 & 33.3 & 33.3 & 0 & 1 & 5 & 3 & 2 & 4 \\
\hline 13 & 0 & 33.3 & 33.3 & 33.3 & 1 & 5 & 3 & 2 & 4 \\
\hline 14 & 33.3 & 0 & 33.3 & 33.3 & 2 & 5 & 3 & 1 & 4 \\
\hline 15 & 33.3 & 33.3 & 0 & 33.3 & 3 & 5 & 2 & 1 & 4 \\
\hline 15 & 25 & 25 & 25 & 25 & 3 & 5 & 2 & 1 & 4 \\
\hline
\end{tabular}

C1: Time of application of the method; C2: Use of specialized equipment; C3: Requirements for chemical or biological inputs;

C4: Improvement of inoculum quality

This makes it possible to emphasize that, although the addition of coagulants such as ferric chloride can be a source of iron, a very important element in the $A D$ of biowaste, this technique has not yet been exhaustively studied as an alternative for the incorporation of this micronutrient [61].

\section{Conclusions}

The use of technological surveillance tools and multicriteria decision analysis, type AHP, allowed an objective and sound selection of the best inoculum-conditioning methodologies identified in the literature, namely, the addition of nutrients and anaerobic digestion using an easily degraded substrate.

Expansion of technological surveillance is recommended, which would incorporate the results published in events of great importance in the field of anaerobic digestion, such as the "Latin American Workshop and Symposium on Anaerobic Digestion" and the "World Congress on Anaerobic Digestion", that have been carried out in the last decades.

\section{Acknowledgments}

The authors thank the experts associated with academic institutions and national and international companies who participated in the panel of experts and the Universidad del Valle for financing the project "Anaerobic digestion of one and two phases of food waste for the production of renewable energy: comparison of the start-up, stability and performance of the process- $\mathrm{Cl} 21006$ ".

\section{References}

[1] A. P. Trzcinski and D. C. Stuckey, "Determination of the hydrolysis constant in the biochemical methane potential test of municipal solid waste," Environmental Engineering Science, vol. 29, no. 9, pp. 848-54, 2012.

[2] L. A. Fdéz., C. Álvarez, D. Sales, and L. I. Romero, "Start-up of thermophilic-dry anaerobic digestion of ofmsw using adapted modified sebac inoculum," Bioresource Technology, vol. 101, no. 23 , pp. 9031-9039, Dec. 2010.

[3] E. Elbeshbishy, G. Nakhlaa, and H. Hafez, "Biochemical methane potential (bmp) of food waste and primary sludge: Influence of inoculum pre-incubation and inoculum source," Bioresource Technology, vol. 110, pp. 18-25, Apr. 2012.

[4] C. Lavergne, D. Jeison, V. Ortega, R. Chamy, and A. Donoso, "A need for a standardization in anaerobic digestion experiments? let's get some insight from meta-analysis and multivariate analysis." Journal of Environmental Management, vol. 15, no. 222, pp. 141-147, Sep. 2018.

[5] N. Qamaruz and M. W. Milke. (2008) Digested sewage sludge as seed for batch test of anaerobic biodegradability. [Online]. Available: https://core.ac.uk/download/pdf/35459994.pdf

[6] M. Fernández, A. Abalos, S. Crombet, and H. Caballero, "Ensayos de biodegradabilidad anaerobia de aguas residuales generadas en una planta refinadora de aceite de soja," Interciencia, vol. 35, no. 8, pp. 600-604, Aug. 2010.

[7] J. D. Nixon, P. K. Dey, S. K. Ghosh, and P. A. Davies, "Evaluation of options for energy recovery from municipal solid waste in india 
using the hierarchical analytical network process," Energy, vol. 59 , pp. 215-223, Sep. 2013.

[8] P. Manyoma, M. Pardo, and P. Torres, "Localización de depósitos internos para residuos sólidos hospitalarios utilizando técnicas multicriterio," Ingeniería y Universidad, vol. 17, no. 2, pp. 443-61, Jul. 2013.

[9] A. Khoshand, H. Kamalan, and H. Rezaei, "Application of analytical hierarchy process (ahp) to assess options of energy recovery from municipal solid waste: a case study in tehran, iran," Journal of Material Cycles and Waste Management, vol. 20, no. 3, pp. 1689-1700, Jul. 2018.

[10] V. V. Lomakin, N. P. Putivtseva, T. V. Zaitseva, M. V. Liferenko, and I. M. Zaitsev, "Multi-critera selection of a corporate system by using paired comparison analysis," J. Fundam. Appl. Sci., vol. 9, no. 7s, pp. 1472-1482, Mar. 2017.

[11] I. B. Huang, J. Keisler, and I. Linkov, "Multi-criteria decision analysis in environmental sciences: Ten years of applications and trends," Science of The Total Environment, vol. 409, no. 19, pp. 3578-3594, Sep. 2011.

[12] E. Gómez, D. F. Navas, G. Aponte, and L. A. Betancourt, “Metodología para la revisión bibliográfica y la gestión de información de temas científicos, a través de su estructuración y sistematización," Dyna, vol. 81, no. 184, pp. 158-163, 2014.

[13] J. Soto, R. Oviedo, P. Torres, L. F. Marmolejo, and P. C. Manyoma, "Compostaje de biorresiduos: Tendencias de investigación y pertinencia en países en desarrollo," Dyna, vol. 84, no. 203, pp. 334-342, 2017.

[14] (2017) Elsevier. productos: Scopus 2017. Elsevier. Accessed En. 10, 2018. [Online]. Available: https://www.scopus.com/search/form. uri?display=basic.

[15] A. Ishizaka and A. Labib, "Review of the main developments in the analytic hierarchy process," Expert Systems with Applications, vol. 38 , no. 11, pp. 14336-14345, 2011.

[16] N. Subramanian and R. Ramanathan, "A review of applications of analytic hierarchy process in operations management," International Journal of Production Economics, vol. 138, no. 2, pp. 215-241, Aug. 2012.

[17] F. Zahedi, "The analytic hierarchy process: A survey of the method and its applications," Interfaces, vol. 16, no. 4, pp. 96-108, Jul. 1986.

[18] D. Podgórski, "Measuring operational performance of osh management system - a demonstration of ahp-based selection of leading key performance indicators," Safety Science, vol. 73, pp. 146-166, Mar. 2015.

[19] J. Fernández, “Optimización de la digestión anaerobia seca de la fracción orgánica de los residuos sólidos urbanos (forsu) en reactores en fases de temperatura," M.S. thesis, Universidad de Cádiz, España, 2010.

[20] B. Wang, S. Strömberg, I. A. Nges, M. Nistor, and J. Liu, "Impacts of inoculum pre-treatments on enzyme activity and biochemical methane potential," J. Biosci. Bioeng., vol. 121, no. 5, pp. 557-60, May 2016.

[21] F. M. Espinoza and et al., "Optimizacion multiple del proceso de digestion anaerobia de vinazas tequileras a temperatura termofílica para la disminucion de la dqo y la generacion de metano," Boletin Nakari, vol. 18, no. 3, pp. 83-8, 2007.

[22] W. Charles, L. Walker, and R. Cord, "Effect of pre-aeration and inoculum on the start-up of batch thermophilic anaerobic digestion of municipal solid waste," Bioresour Technol., vol. 100, no. 8, pp. 2329-35, Apr. 2009.

[23] G. Silvestre, A. Rodríguez, B. Fernández, X. Flotats, and A. Bonmatí, "Biomass adaptation over anaerobic co-digestion of sewage sludge and trapped grease waste," Bioresour Technol., vol. 102, no. 13, pp. 6830-6, Jul. 2011.

[24] W. A. Mosos, L. S. Cadavid, and A. C. Agudelo, "Potencial de biogás de residuos de frutas y verduras provenientes de restaurantes de palmira," Acta Agron., vol. 61, no. 5, pp. 97-98, 2012.

[25] Y. Li and et al., "Influence of inoculum source and pre-incubation on bio-methane potential of chicken manure and corn stover." Appl. Biochem. Biotechnol., vol. 171, no. 1, pp. 117-27, Sep. 2013.

[26] Z. Sapci, J. Morken, and R. Linjordet, "An investigation of the enhancement of biogas yields from lignocellulosic material using two pretreatment methods: Microwave irradiation and steam explosion," BioResources, vol. 8, no. 2, pp. 1976-85, 2013.

[27] P. Ferrer, M. Cambra, A. Cerisuelo, D. S.Peñaranda, and V. Moset, "The use of agricultural substrates to improve methane yield in anaerobic co-digestion with pig slurry: Effect of substrate type and inclusion level," Waste Management, vol. 34, no. 1, pp. 196-203, Jan. 2014.

[28] J. Shi and et al., "Effects of microbial and non-microbial factors of liquid anaerobic digestion effluent as inoculum on solid-state anaerobic digestion of corn stover," Bioresource Technology, vol. 157, pp. 188-196, Apr. 2014.

[29] G. Wordofa, "Effect of thermal pretreatment on chemical composition and biogas production from kitchen waste," M.S. thesis, University of Jyväskylä, Jyväskylä, Finlandia, 2014.

[30] X. Liu, S. M. Zicari, G. Liu, Y. Li, and R. Zhang, "Pretreatment of wheat straw with potassium hydroxide for increasing enzymatic and microbial degradability," Bioresource Technology, vol. 185, pp. 150-157, Jun. 2015

[31] G. Silvestre, A. Bonmatí, and B. Fernández, "Optimisation of sewage sludge anaerobic digestion through co-digestion with ofmsw: Effect of collection system and particle size," Waste Management, vol. 43, pp. 137-143, Sep. 2015.

[32] G. Zhen, X. Lu, T. Kobayashi, Y. Li, K. Xu, and Y. Zhao, “Mesophilic anaerobic co-digestion of waste activated sludge and egeria densa: Performance assessment and kinetic analysis," Applied Energy, vol. 148, pp. 78-86, Jun. 2015.

[33] L. S. Cadavid and I. V. Bolaños, "Grass from public green spaces an alternative source of renewable energy in tropical countries," Revista ION, vol. 29, no. 1, pp. 109-16, Jan. 2016.

[34] P. Tsapekos, P. G. Kougias, A. Frison, R. Raga, and L. Angelidaki, "Improving methane production from digested manure biofibers by mechanical and thermal alkaline pretreatment," Bioresour. Technol., vol. 216, pp. 545-52, Sep. 2016.

[35] Z. Jian, W. Shuangfei, L. Shiguang, X. Ping, and X. Tian, "Kinetics of combined thermal pretreatment and anaerobic digestion of waste activated sludge from sugar and pulp industry," Chemical Engineering Journal, vol. 295, pp. 131-138, Jul. 2016.

[36] N. Nakasima and et al., "Inoculum adaptation during start-up of anaerobic digestion of organic solid waste," Inf. tecnol., vol. 28, no. 1, pp. 199-208, 2017.

[37] R. E. Salazar, "Influencia en la adición de un coagulante en el mejoramiento de la calidad de un inóculo para optimizar el arranque de un reactor UASB," Undergraduate thesis, Facultad de Ingenieria, Universidad del Valle, Cali, Colombia, 2001.

[38] P. Torres, A. Cardoso, and O. Rojas, "Mejoramiento de la calidad de lodos anaerobios. influencia de la adición de cloruro férrico," Ingeniería y Competitividad, vol. 5, no. 2, pp. 23-31, 2004.

[39] W. Choorit and P. Wisarnwan, "Effect of temperature on the anaerobic digestion of palm oil mill effluent," Electronic Journal of Biotechnology, vol. 10, no. 3, pp. 376-85, Jul. 2007.

[40] P. Lins, C. Reitschuler, and P. Illmer, "Development and evaluation of inocula combating high acetate concentrations during the start-up of an anaerobic digestion," Bioresource Technology, vol. 110, pp. 167-173, Apr. 2012.

[41] I. Cabeza, V. Thomas, A. Vásquez, P. Acevedo, and M. Hernández, "Anaerobic co-digestion of organic residues from different productive sectors in colombia: Biomethanation potential assessment," Chemical Engineering Transactions, vol. 49, pp. 385-90, 2016.

[42] W. Suksong, P. Kongjan, P. Prasertsan, T. Imai, and S. O-Thong, "Optimization and microbial community analysis for production of biogas from solid waste residues of palm oil mill industry by solid-state anaerobic digestion," Bioresource Technology, vol. 214, pp. 166-174, Aug. 2016.

[43] M. Wojcieszak and et al., "Adaptation of methanogenic inocula to anaerobic digestion of maize silage," Frontiers in Microbiology, vol. 8 , 2017.

[44] Q. Yang, L. H. Wei, W. Li, Y. Chen, and M. T. Ju, "Effects of feedstock sources on inoculant acclimatization: Start-up strategies 
and reactor performance," Appl. Biochem. Biotechnol., vol. 183, no. 3 , pp. 729-743, Nov. 2017.

[45] A. G. Vlyssides and P. K. Karlis, "Thermal-alkaline solubilization of waste activated sludge as a pre-treatment stage for anaerobic digestion," Bioresource Technology, vol. 91, no. 2, pp. 201-206, Jan. 2004.

[46] S. E. Vigueras, F. Ramírez, A. Noyola, and O. Monroy, “Effect of thermal alkaline pretreatment on the anaerobic digestion of wasted activated sludge," Revista mexicana de ingeniería química, vol. 10, no. 2, pp. 247-255, Aug. 2011.

[47] M. Collazos, J. Valencia, J. Rodríguez, and O. Rojas, “Influencia del proceso de elutriación en el mejoramiento de un inóculo de mala calida para optimizar el arranque de un reactor uasb," unpublished.

[48] J. Shi, Z. Wang, J. A. Stiverson, Z. Yu, and Y. Li, "Reactor performance and microbial community dynamics during solid-state anaerobic digestion of corn stover at mesophilic and thermophilic conditions," Bioresour Technol., vol. 136, pp. 574-81, May 2013.

[49] I. Angelidaki and et al., "Defining the biomethane potential (bmp) of solid organic wastes and energy crops: a proposed protocol for batch assays." Water. Sci. Technol., vol. 59, no. 5, pp. 927-34, 2009.

[50] F. Raposo, M. A. D. la Rubia, V. Fernández, and R. Borja, "Anaerobic digestion of solid organic substrates in batch mode: An overview relating to methane yields and experimental procedures," Renewable and Sustainable Energy Reviews, vol. 16, no. 1, pp. 861-877, Jan. 2012.

[51] B. A. Parra, L. S. Angulo, J. S. Loaiza, W. A. Torres, and P. Torres, "Inoculum mixture optimization as strategy for to improve the anaerobic digestion of food waste for the methane production," Journal of Environmental Chemical Engineering, vol. 6, no. 1, pp. 1529-1535, Feb. 2018.

[52] P. Torres, S. J. Granados, and B. A. Orobio, "Effects of the incorporation of drinking water sludge on the anaerobic digestion of domestic wastewater sludge for methane production," Water Sci. Technol., vol. 72, no. 6, pp. 1016-21, 2015.
[53] M. Romero, J. Vila, J. Mata, J. M. Chimenos, and S. Astals, "The role of additives on anaerobic digestion: A review," Renewable and Sustainable Energy Reviews, vol. 58, pp. 1486-1499, May 2016.

[54] E. Ortega-Martinez, I. Sapkaite, F. Fdz-Polanco, and A. Donoso-Bravo, "From pre-treatment toward inter-treatment. getting some clues from sewage sludge biomethanation," Bioresource Technology, vol. 212, pp. 227 - 235, Jul. 2016.

[55] J. Ariunbaatar, A. Panico, G. Esposito, F. Pirozzi, and P. N. Lens, "Pretreatment methods to enhance anaerobic digestion of organic solid waste," Applied Energy, vol. 123, pp. 143-156, Jun. 2014.

[56] W. M. Budzianowski, "A review of potential innovations for production, conditioning and utilization of biogas with multiple-criteria assessment," Renewable and Sustainable Energy Reviews, vol. 54, pp. 1148-1171, Feb. 2016.

[57] Z. Naji and et al., "Batch anaerobic co-digestion of ofmsw lorganic fraction of municipal solid waste), twas (thickened waste activated sludge) and rs (rice straw): Influence of twas and rs pretreatment and mixing ratio," Energy, vol. 107, pp. 131-140, Jul. 2016.

[58] A. J. Ward, P. J. Hobbs, P. J. Holliman, and D. L. Jones, "Optimisation of the anaerobic digestion of agricultural resources," Bioresource Technology, vol. 99, no. 17, pp. 7928-7940, Nov. 2008.

[59] B. A. Parra and et al., "EvaluaciÃde lodos de PTAR municipales como inÃen la digestiÃanaerobia de biorresiduos," Revista ION, vol. 29, pp. 37-46, jun 2016.

[60] C. Holliger and et al., "Towards a standardization of biomethane potential tests," Water Sci. Technol., vol. 74, no. 11, pp. 2515-2522, Dec. 2016.

[61] G. Capson-Tojo, C. Girard, M. Rouez, M. Crest, J.-P. Steyer, N. Bernet, J.-P. Delgenès, and R. Escudié, "Addition of biochar and trace elements in the form of industrial fecl 3 to stabilize anaerobic digestion of food waste: dosage optimization and long-term study," Journal of Chemical Technology \& Biotechnology, vol. 94, no. 2, pp. 505-515, 2019. 